Article

\title{
Dendrochronological Analyses and Whole-Tree Dissections Reveal Caliciopsis Canker (Caliciopsis pinea) Damage Associated with the Declining Growth and Climatic Stressors of Eastern White Pine (Pinus strobus)
}

\author{
Kara K.L. Costanza ${ }^{1,2, *}$, William H. Livingston ${ }^{1}$, Shawn Fraver ${ }^{1}$ and Isabel A. Munck ${ }^{3}$ (D) \\ 1 School of Forest Resources, University of Maine, Orono, ME 04469, USA; WilliamL@maine.edu (W.H.L.); \\ Shawn.Fraver@maine.edu (S.F.) \\ 2 USDA Forest Service, Northern Region, State and Private Forestry, Forest Health Protection, \\ Missoula, MT 59804, USA \\ 3 USDA Forest Service, Northeastern Area, State and Private Forestry, Forest Health Protection, \\ Durham, NH 03824, USA; Isabel.Munck@usda.gov \\ * Correspondence: Kara.Costanza@usda.gov; Tel.: +1-406-329-3281
}

Received: 3 March 2020; Accepted: 17 March 2020; Published: 20 March 2020

\begin{abstract}
Eastern white pine (Pinus strobus) is considered a signature species in eastern North America, particularly in New England. In recent years, however, white pine has experienced increased damage due to native pathogens that reduce the species' growth, productivity, and economic value. One disease of concern is Caliciopsis canker, caused by the fungal pathogen Caliciopsis pinea, which is associated with excessive resin production, cankers, rough bark, bark fissures/cracks, and reduced growth in white pine. Recent studies have documented the extent of Caliciopsis canker in New England and its association with soil and stocking conditions, yet few studies have focused on the biological impacts of the disease. This study used dendrochronology and whole-tree dissections to reconstruct Caliciopsis canker history in three New England white pine sites, quantify its impact on tree growth and vigor, identify pre-disposing factors, and assess potential silvicultural management options. Dendrochronology and whole-tree dissections provided a unique insight into canker damage throughout trees' development. Canker damage was first reported in New Hampshire in the mid-1990s, yet cankers were present as far back as 1967 and have steadily increased since the mid-1980s. Increased canker damage was significantly associated with decreased live crown ratios and declining tree growth. Trees maintaining a 30\% live crown ratio or greater generally experienced the least canker damage. Furthermore, peaks in canker occurrence were consistent across sites, indicating a regional synchronization of infection and damage. Canker damage was closely associated with climatic events such as droughts and a New England hurricane. The results suggest that Caliciopsis canker has been affecting white pine health over the last 40 years, and that the disease has become more prevalent in the past 20-30 years. Yet, our results suggest that if silvicultural prescriptions target low density thinnings that favor trees with higher live crown ratios $(>30 \%)$ and low Caliciopsis symptom severity ratings, the risk of canker damage can be reduced in white pine stands.
\end{abstract}

Keywords: Caliciopsis canker; dendrochronology; eastern white pine; tree-pathogen interaction

\section{Introduction}

There is growing evidence that forest pests and pathogens are causing increased damage worldwide [1]. As globalization continues to increase economic trade, pests and pathogens can likewise 
be spread [2,3]. Climate change, however, is gaining recognition as another driving factor that can allow range expansion and redistribution, particularly for insects given their short life cycles, dispersal abilities, and temperature sensitivities [4,5]. Less is known about the direct effect of climate change on fungal pathogens; however, there is concern that these too may be enhanced by the indirect effects of increased forest disturbance and tree stress associated with climate change [6-8].

Throughout eastern North America, eastern white pine (Pinus strobus L.) is experiencing novel changes in both insect and fungal interactions, making it an ideal study species [9]. There is also a persistent background level of predisposing stressors caused by site factors, disturbance regimes, and climatic factors. For example, white pine is typically found on well-drained, sandy, and slightly acidic soils. It is also found on excessively drained soils and poorly drained soils where there is minimal hardwood competition. On such sites, the lack of soil water or shallow rooting predisposes white pine to water stress, which limits tree growth and substantially reduces tree vigor; these stressed trees lack resistance to insect and fungal agents [10-15].

Numerous studies have documented the interaction between water stress and fungal pathogens in tree disease [13,14,16-19]. As noted in these studies, drought conditions may result in decreased crown density and reductions in tree growth, foliar biomass, net photosynthetic capacity, stomatal conductance, disease resistance, and tree vigor. While broad concepts have been explored in these studies, few individual host-pathogen interactions have been studied in relation to climate. In white pine forests specifically, little research has been conducted on the relationship between climatic stress and host-tree susceptibility to specific pathogens, with the exception of white pine needle damage and white pine blister rust $[8,20]$. In the face of climate change and altered disturbance regimes, understanding the relationships between climatic variables and pathogen establishment is critical for managing healthy forests.

One fungal pathogen has recently become an increasing concern in white pine stands: Caliciopsis pinea Peck, a canker-forming ascomycete of the Coryneliaceae family thought to cause Caliciopsis canker disease. This native pathogen was first documented in 1880 in Charlton, NY, USA [21], and has since been reported on eastern white pine, shortleaf pine (P. echinata Mill), Table Mountain pine (P. pungens Lamb), pitch pine (P. rigida Mill), loblolly pine (P. taeda L.), and Virginia pine (P. virginiana Mill) in eastern North America [22-24]. The fungus has also been reported on conifers in western North America and European Pinus species [24-27]. Spores of C. pinea are likely spread via stem runoff, rain splash, wind, or possibly insect transport [26,28]. Once disseminated, it has been hypothesized that C. pinea spores require a "port of entry in order to penetrate the host tissue" [26]. Previous studies suggest entry can occur through natural and artificial wounds, natural bark cracks, insect feeding sites, foliar scars, and lenticels [23,26,28-30]. Once infected, host symptoms include excessive resin production, crown thinning, roughened bark, sunken brown/red depressed lesions, bark fissures/cracks, necrotic tissue, and reduced wood quality (Figure 1A-F) [24,25,30-32]. Ascocarps may also be present on roughened bark or at branch axils, with long black stromata that resemble eyelash clusters $[9,24,25]$. However, these fruiting bodies are not consistently present and are often absent near older infections. White pine of all ages and size classes are affected [24,33]. 


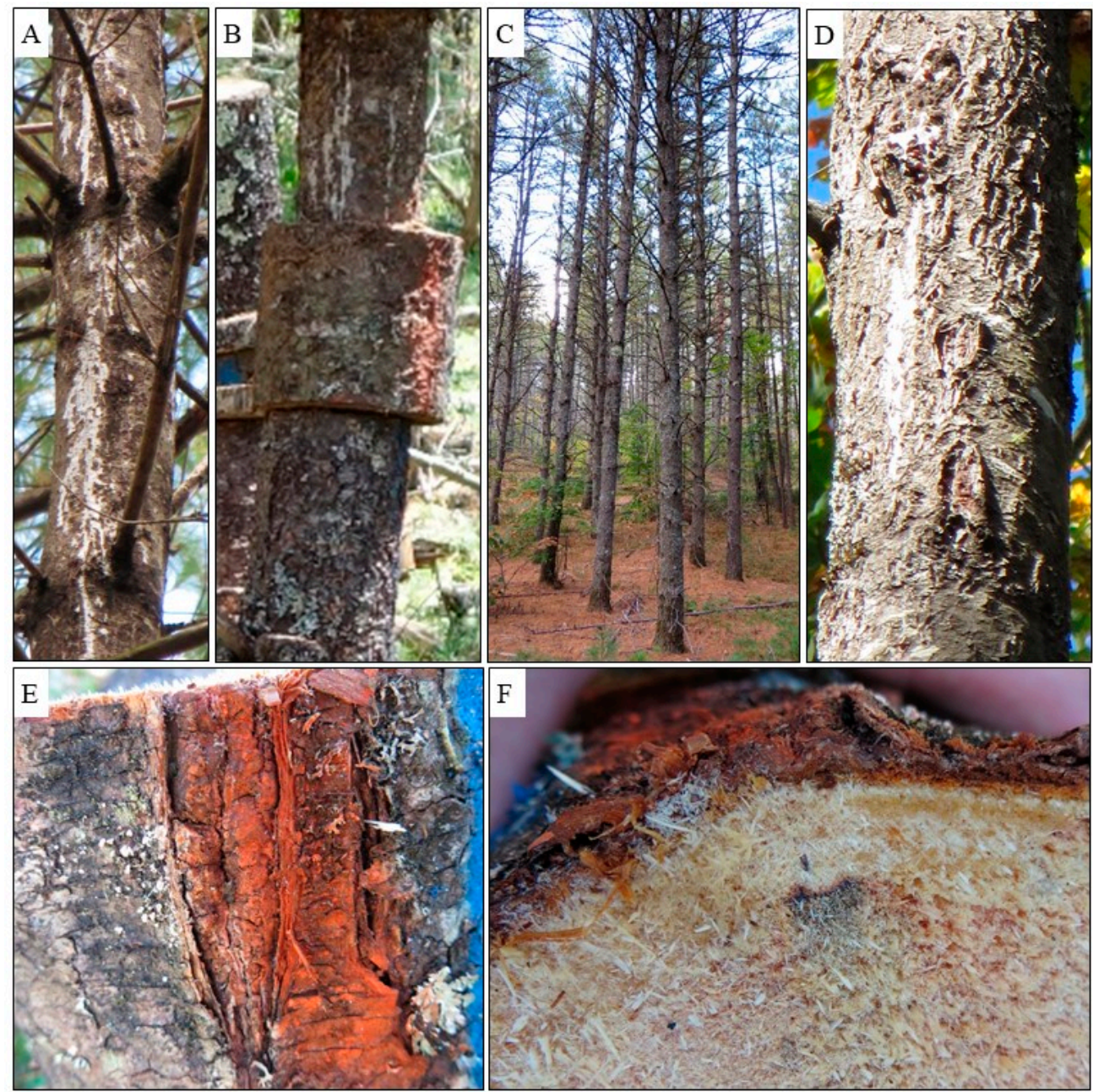

Figure 1. Common symptoms of Caliciopsis canker damage. Symptoms include (A,B) heavy resin production, particularly between whorls, (C) thinning crowns with as little as 5\% live crown, (D) roughened bark in the mid- to upper-crown, (E) bark fissures/cracks, which are associated with (F) necrotic tissue and internal cankers. The (F) internal canker with necrotic tissue is associated with the (E) large bark crack that has sealed over.

Reports of canker occurrence and associated white pine damage have been increasing, particularly in eastern North America [24,28,33-36]. Caliciopsis-related damage was reported in 1997 in the northeastern USA [28], by 2003 in Québec, Canada [37], and in 2006 in the southeastern and midwestern USA $[30,35]$. Some of the most severe damage occurs in pole-sized white pine stands, with more than $70 \%$ of sites in New Hampshire being symptomatic [28], as well as pockets of tree mortality in the midwestern, southeastern, and northeastern USA [24,28,30,33,34]. To monitor and evaluate Caliciopsis canker severity, the USA Forest Service recently developed an assessment protocol that recommends dividing white pine tree stems into thirds and counting the number of Caliciopsis canker-associated resin streaks per third [24].

To quantify tree responses to forest pests and pathogens, studies have frequently used dendrochronology. However, the majority of this research has focused on insects (e.g., [38-41]). Furthermore, past research has either reconstructed pest/pathogen arrival and damage history (e.g., [39,41,42]), or has focused on changes in tree growth and volume (e.g., [38,40]). To date, dendrochronology and whole-tree dissections have not been used to reconstruct the history of a fungal pathogen and quantify tree response to infections on a whole-tree level. 
Objectives: Given the ecological and economic importance of white pine throughout its range, there is strong interest in maintaining the health and productivity of the species. Despite some basic biological information on Caliciopsis canker (discussed above), very little is known about its impact on white pine or the factors that may predispose trees to this disease. Our general objective was to fill these knowledge gaps, using dendrochronological and field data from three study sites in northern New England. Specific objectives included (1) reconstructing the sequence of Caliciopsis cankers over time; (2) quantifying the relationship between Caliciopsis cankers and white pine growth and vigor; (3) identifying pre-disposing factors that may increase the likelihood of Caliciopsis canker incidence and severity; and (4) evaluating the response of stands affected by Caliciopsis canker to thinnings. We hypothesize that Caliciopsis canker is reducing white pine growth and vigor, particularly in stressed and weakened trees. Stressors likely include soils, climatic variables such as drought, and overstocking. We further hypothesize that trees from thinned stands will have lower canker incidence and severity, and better growth recovery post-infection. Taken together, the information gained by addressing these objectives may guide silvicultural prescriptions aimed at mitigating damage from future infections.

\section{Materials and Methods}

\subsection{Study Area}

Study sites are located in the Northeastern Highlands Ecoregion in New England, which includes the Adirondacks in New York, the majority of Vermont and New Hampshire, and western Maine [43]. The region is characterized by cool temperatures, with many subregions being transitional between temperate and boreal zones. Soil types vary, but spodosols are common, often with sandy loam or loamy sand. Soils are typically nutrient-poor and range from well drained to poorly drained. Mean annual soil temperatures are frigid, ranging from 0 to $8{ }^{\circ} \mathrm{C}$ [43].

\subsection{Site and Stand Selection}

Three sites were selected in northern New England: N1 and N2 in central New Hampshire and M3 in southwestern Maine. The sites had a history of Caliciopsis canker damage and occurred on previous agricultural land. Since the 1930s, sites developed without disturbance, except for the harvesting of a few random trees. From 2000-2010, a portion of each site was thinned to approximately 250 trees per hectare. Thinnings occurred in December 1999/January 2000 at N1, 2010 at N2, and 2004 at M3. Our study selected a thinned and unthinned stand from each site, in close proximity to one another $(<0.5 \mathrm{~km}$ apart).

The sample sites had annual mean temperatures ranging from 6.9 to $7.6^{\circ} \mathrm{C}$, minimum temperatures from 0.8 to $1.2{ }^{\circ} \mathrm{C}$, and maximum temperatures from 13.0 to $13.9^{\circ} \mathrm{C}$ (Table A1) [44]. The annual precipitation ranges from 111.2 to $117.9 \mathrm{~cm}$ (Table A1) [44]. In general, the sites occurred on moderately to poorly drained sandy soils, where white pine comprised at least $75 \%$ of the site basal area [24].

Within each stand, trees were similarly aged, with individuals frequently developing from a single cohort. Age was verified by collecting stem cross-sections at breast height $(1.37 \mathrm{~m})$, dating the innermost year, and correcting for rings between 0 and $1.3 \mathrm{~m}$ [45]. Estimated establishment years ranged from 1934-1940 (N1), 1944-1964 (N2), and 1937-1957 (M3).

During site selection, the severity of Caliciopsis canker-associated symptoms on each white pine tree was assessed, resulting in two severity classes: (1) low severity, with zero to few external symptoms; and (2) high severity, with numerous symptoms (fully defined in [32]). The presence of C. pinea in trees was confirmed using both a culture-based approach and a molecular diagnostic assay ([46], Broders and Wyka unpubl. data).

\subsection{Field Sampling}

At the center of each stand, plots similar to Forest Inventory and Analysis (FIA) Phase 2 plots were established; the plots consisted of four 7.32-m radius subplots in a tetrahedral shape [47]. 
Within the subplots, all trees $\geq 1.0 \mathrm{~cm}$ diameter at breast height $(\mathrm{dbh}, 1.37 \mathrm{~m})$ were sampled for species, $\mathrm{dbh}$, and crown class [47]. Additional data were recorded for white pines $\geq 12.7 \mathrm{~cm} \mathrm{dbh}$, including tree height, uncompacted live crown ratio (UNCR), and crown metrics such as width, transparency, density, and dieback. Tree- and stand-level metrics were calculated including basal area, volume, and trees per hectare.

Following initial data collection, six white pine trees per stand were destructively sampled (36 trees total) from May-August, 2015. In each stand, the three most affected trees in the high severity class and the three least affected trees in the low severity class were selected. The trees were felled and subsequently dissected into $0.3 \mathrm{~m}$ long bolts (see Figure $1 \mathrm{~B}$ for example of bolts). Each bolt was inspected for Caliciopsis canker damage (as defined in Figure 1), from the base of the tree up to a 5 $\mathrm{cm}$ diameter. If cankers were present, a $2.54 \mathrm{~cm}$ thick cross-section was cut from the bottom of the bolt. For each canker, the data collected included: (a) canker width, measured from necrotic edge to necrotic edge, along the circumference of the annual ring; (b) canker height on the tree, measured as the specific height of the tree from soil to the exposed canker; and (c) the presence/absence of external symptoms associated with the canker, including resinosis, roughened bark, brown/red lesions, or bark fissures/cracks. From these field cross-sections, every third sample was returned to the Tree-Ring Laboratory at the University of Maine, totaling 318 cross-sections. This subset was selected to ensure a manageable sample size. An additional cross-section was taken from every tree at breast height; all 36 of these cross-sections were also returned to the University of Maine.

\subsection{Cross-Section Preparation and Tree Ring Measurements}

Cross-sections were dried for $30+$ days. Following drying, the bottom of each cross-section was sanded with progressively finer sandpaper (100 through 1200 grit) using belt and random orbital sanders, until individual cells were easily visible under a stereoscope. Processed samples were crossdated by hand using the skeleton plot method, then verified by two additional researchers. On the 318 cross-sections with cankers, all cankers were numbered and dated. The year of canker formation was the earliest year with cell disruption and necrosis. The year of recovery was the year that ring width was no longer declining at the canker, according to visual estimation (Figure 2).

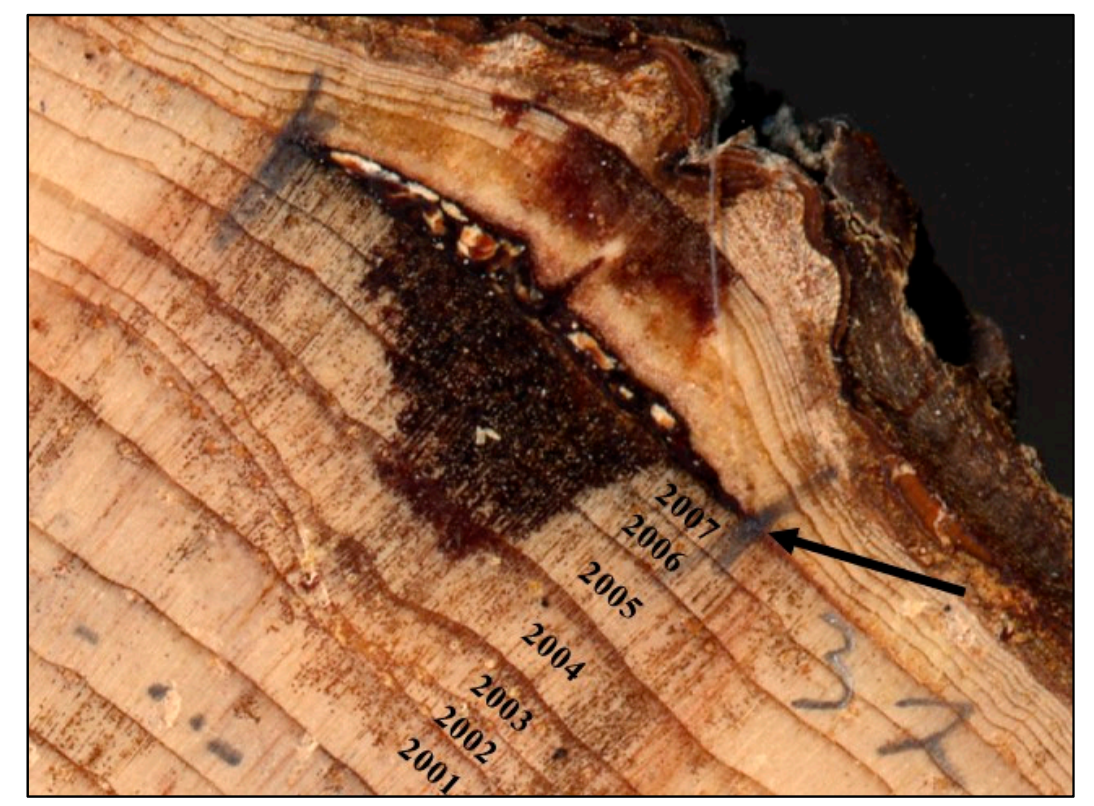

Figure 2. Cross-section of a white pine tree documenting annual rings and canker 32. Canker 32 formed in the earlywood of 2008 (black arrow) and had no recovery year, as annual ring width continued to decline post-canker. 
All samples were scanned on an Epson Expression 1640 XL flatbed scanner (Epson America, Long Beach, CA, USA) at 800-1200 dpi (dependent on cross-section size and ring width), in color, and saved as TIFF files. Images from the 318 cross-sections with cankers were imported into ImageJ 1.x, an image analysis program [48]. In ImageJ, lines were drawn over each canker to measure canker width. Width was measured from necrotic edge to necrotic edge, along the circumference of the ring.

Images from the 36 breast height cross-sections were imported and measured using the image analysis software WinDENDRO v.2012b (Regent Instruments, Québec, CA, Canada) [49]. Annual ring widths were measured to the nearest $0.001 \mathrm{~mm}$ from pith to bark along four separate paths, at approximately $90^{\circ}$ angles from one another. The four paths were averaged for each cross-section, creating one annual ring width chronology per cross-section. Crossdating accuracy was verified using COFECHA [50], and discrepancies were corrected where necessary.

\subsection{Analyses}

From the 318 cross-sections, 835 cankers were originally identified. However, questionable damage that was not definitively associated with Caliciopsis canker damage was removed from the dataset prior to analysis (65 of 835 cankers removed). These removed cankers were assessed through visual observation of damage after cross-sections had been sanded and included damage that did not have necrosis or that was associated with other factors (e.g., insects, abiotic stress, etc.). The remainder (770 cankers) had Caliciopsis canker symptoms (Figure 1) that were associated with C. pinea infections in other studies $([9,32,51]$, Broders and Wyka unpub. Data). Furthermore, DNA from a subset of cankers was tested using Caliciopsis spp. primers, and despite difficulty in isolating DNA from older cankers, C. pinea was successfully isolated [46]. The dates assigned to each canker were used to reconstruct the history of Caliciopsis canker incidence in each stand. It was assumed that if cankers were randomly dispersed in time, then an individual driver or event would not be associated with increases in canker incidence (number of cankers) and severity (width of cankers). Conversely, if cankers were clustered in specific years, it would indicate a disturbance affecting the host or an event favoring pathogen dispersal potentially coinciding with canker occurrence, particularly if all sites experienced identical cluster years.

To quantify tree-level response to Caliciopsis canker damage, two dependent variables (the number of cankers, the width of cankers) and three independent variables (UNCR, annual basal area increment, annual decline score) were calculated. The dbh and height of the sample trees varied dramatically and likely influenced the number of cankers measured per cross-section, as well as the number of bolts that showed canker damage. Therefore, developing dependent variables that accounted for tree size was critical to accurately assess canker damage. The number of cankers reflects the number of infections. Alternatively, the cumulative width of cankers can provide a more reliable estimate of canker influence on individual tree health and vigor. As a result, both metrics were included as dependent variables. These metrics were summed across the sample cross-sections analyzed (approximately one-third of the cankered sections from each tree). To adjust metrics for tree size, each canker metric was divided by the volume $\left(\mathrm{m}^{3}\right)$ of each sample (volume calculations in [52]). These adjusted canker metrics will be referred to as the canker incidence index and canker severity index.

Crown metrics (UNCR) were measured in the field for every sample tree, according to FIA Phase 2 Protocol [47]. A clinometer was used to measure the tree's base, base of live crown (lowest live branch, not compacted), and tip (living top of tree). The whole tree length was calculated (top-base) and then the crown length (top-base of live crown). Finally, the crown length was divided by the whole tree length to calculate UNCR. Additionally, each canker's height on the tree was recorded in the field, and rounded to the nearest $0.3 \mathrm{~m}$.

To test if there were differences in tree measurements among sites and treatments, analyses of variance (ANOVA) were run in R version 3.4.3 [53]. Thinning treatment (thinned vs. unthinned) and Caliciopsis symptom severity class (low vs. high) were fixed effects, while dbh, height, volume, 
and UNCR were each run as individual response variables. Site was part of the blocking design and was treated as a random factor.

To assess the relationship between canker damage and UNCR (a measureable external characteristic of tree health), linear mixed effects models were run for each dependent variable (number of cankers $/ \mathrm{m}^{3}$ and width of cankers $/ \mathrm{m}^{3}$ ) using the lme4 package in $\mathrm{R}[53,54]$. Thinning treatment, Caliciopsis symptom severity class, UNCR, and their interactions were fixed effects, while site was treated as a random factor.

Annual basal area increments (BAI) were calculated using raw ring width measurements, for every cross-section collected at dbh, using the bai.out function from the dplR package in $R[53,55]$. From these BAI values, an annual decline score $\left(D_{\text {score }}\right)$ was calculated for each tree to identify the years in which trees were declining in growth and the years in which they were recovering (Equation (1)). This equation is a modified version of that developed by Livingston et al. [56].

Equation (1): Decline score equation using a modified version of Livingston et al.'s [56] $\mathrm{D}_{\text {score }}$ methodology, which calculates an annual decline score for every tree, using annual basal area increments.

$$
\mathrm{D}_{\text {score }_{\mathrm{x}}}=-1 * \frac{\left\{\left[\frac{\left(\mathrm{BAI}_{\mathrm{x}-3}+\mathrm{BAI}_{\mathrm{x}-2}+\mathrm{BAI}_{\mathrm{x}-1}\right)}{3}\right]-\left[\frac{\left(\mathrm{BAI}_{\mathrm{x}}+\mathrm{BAI}_{\mathrm{x}+1}+\mathrm{BAI}_{\mathrm{x}+2}\right)}{3}\right]\right\}}{\left[\sqrt{\mathrm{VAR}_{\mathrm{x}}} * \sqrt{\frac{2}{3}}\right]}
$$

$\mathrm{X}=$ year for which $\mathrm{D}_{\text {score }}$ is being calculated,

$\mathrm{BAI}=$ basal area increment for year in subscript,

$\mathrm{VAR}_{\mathrm{x}}=$ the pooled variance of the means (Equation (2))

Equation (2): Pooled variance equation.

$$
\mathrm{VAR}_{\mathrm{x}}=\frac{\frac{\sum_{\mathrm{i}=\mathrm{x}-3}^{\mathrm{x}-1}\left(\mathrm{BAI}_{\mathrm{i}}-\frac{\sum_{\mathrm{i}=\mathrm{x}-3}^{\mathrm{x}-1} \mathrm{BAI}_{\mathrm{i}}}{3}\right)^{2}}{2}+\frac{\sum_{\mathrm{i}=\mathrm{x}}^{\mathrm{x}+2}\left(\mathrm{BAI}_{\mathrm{i}}-\frac{\sum_{\mathrm{i}=\mathrm{x}}^{\mathrm{x}+2} \mathrm{BAI}_{\mathrm{i}}}{3}\right)^{2}}{2}}{2}
$$

Within the $\mathrm{D}_{\text {score }}$ equation, a short three-year period was specifically selected to identify periods of decline that develop quickly, such as those in response to C. pinea infection, which might not otherwise be detected with longer periods [56].

In order to identify potential risk factors that may increase the likelihood of Caliciopsis canker damage, the $\mathrm{D}_{\text {score }}$ was plotted against major regional stress events, determined from historical records, and canker damage metrics. Stress events were graphed as three-year windows: year one was the event, while years two and three were the potential response period. Events include the 1957 drought (1957-1959), the 1965 drought (1965-1967), the 1978 drought (1978-1980 in M3), the 1981 drought (1981-1983 in N1 and N2), the 1995 drought (1995-1997, most severe in M3), the 1999 drought (1999-2001, which also includes droughts in 2000 and 2001), Hurricane Floyd in September 1999 (1999-2001, most severe in N1 and N2), and the 2007 drought (2007-2009) [57-59]. We hypothesized that lower $\mathrm{D}_{\text {score }}$ values would be associated with (A) stress events, (B) higher canker damage metrics $[24,33,36,60],(C)$ both stressors and canker damage, or (D) none of the above.

Potential risk factors were then evaluated by comparing the $\mathrm{D}_{\text {score }}$ with the year of canker formation and periods of climatic stress, focusing on when cankers occurred during the decline cycle. A decline is any period with a $\mathrm{D}_{\text {score }}<0$ for three or more consecutive years. The tree is in recovery when the $\mathrm{D}_{\text {score }}$ is $\geq 0$ for two or more consecutive years. This period between the start of decline

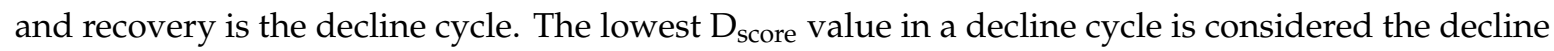
maximum [56]. If canker damage consistently occurs at the start of decline cycles, it is assumed that canker damage induces declining growth. Conversely, if canker damage occurs at or after the decline maximum, it is presumed that the tree was already declining before infection. If canker damage occurs independent of decline cycles, it is assumed that tree growth is not directly related to canker damage. Additionally, if canker damage corresponds with the maximum $\mathrm{D}_{\text {score }}$ and occurs with or immediately 
following climatic stress, the stressor is assumed to have predisposed the tree to fungal infection and canker formation [61]. These evaluations will improve our understanding of how white pine interacts with $C$. pinea, which will shed light on the risk factors that may increase canker incidence and severity in the species.

The role of Caliciopsis symptom severity was considered by evaluating the relationship between $\mathrm{D}_{\text {scores }}$ and canker damage in high severity versus low severity trees at each site. We hypothesized that high severity trees would have more years with negative $\mathrm{D}_{\text {scores, }}$ and that there would be greater

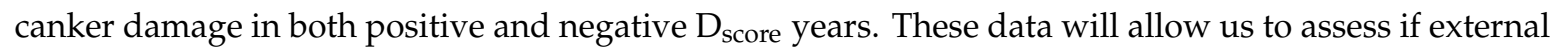
symptom assessments (Caliciopsis symptom severity class and UNCR) can accurately predict which trees experience greater canker damage, and if highly affected trees experience greater growth declines, all with the intention of developing a successful management strategy for Caliciopsis canker.

\section{Results}

Caliciopsis cankers first appeared in sampled sites decades earlier than initial reports indicated: 1968 at N1, 1989 at N2, and 1974 at M3 (Figure 3). Cankers occurred in low numbers until the mid-1980s (M3) to mid-1990s (N1 and N2), at which point canker incidence increased and maintained higher numbers at all three sites (Figure 3). Particularly high canker incidence occurred in 1986 (M3), 1997 (N1, M3), 2000 (all), 2005 (M3), and 2008 (N1, N2) (Figure 3). The cankers are neither randomly nor evenly distributed; they are aggregated in spike years that frequently occur at more than one site.

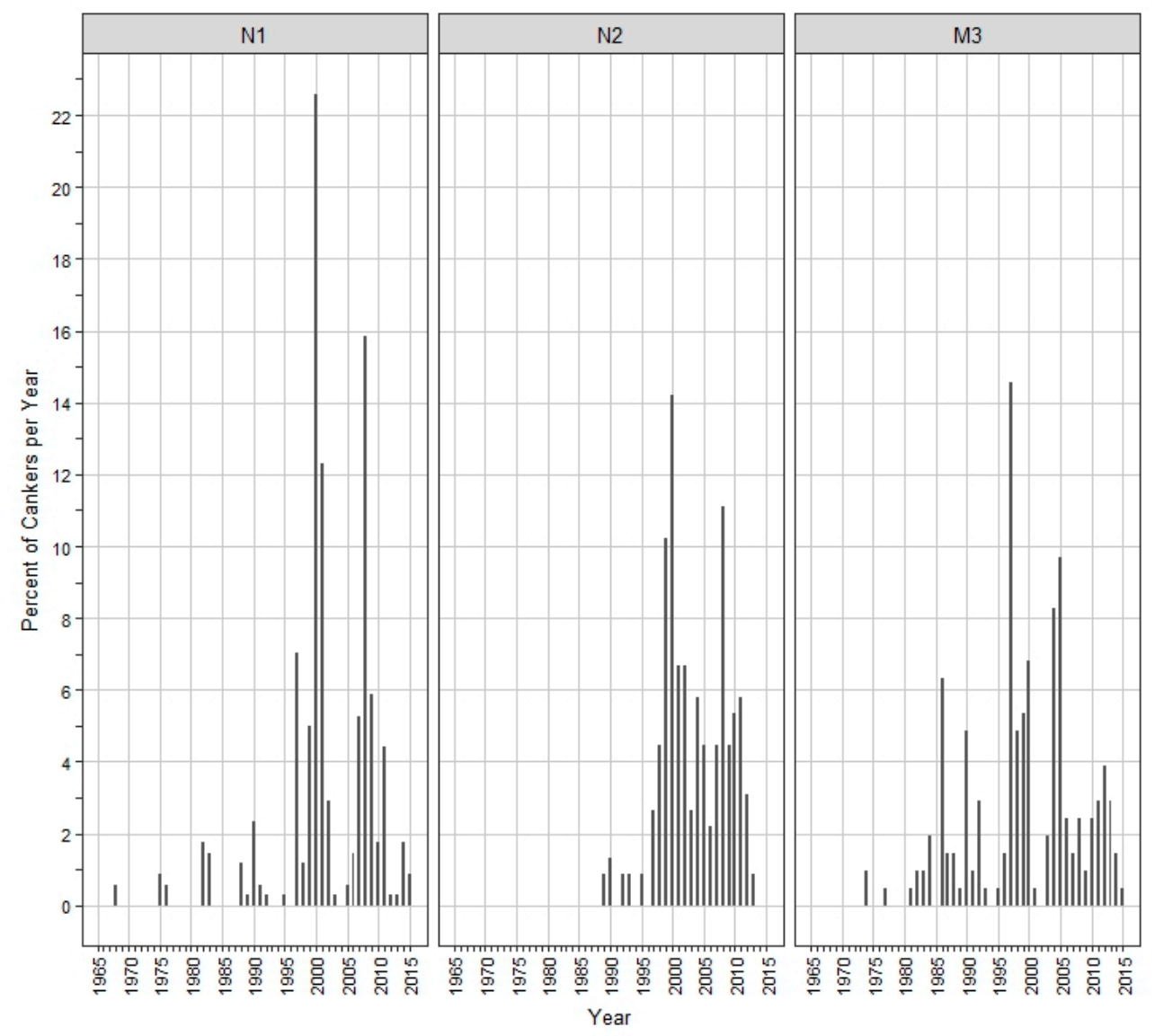

Figure 3. Canker history in each of three sampled stands: N1, N2, and M3. The vertical bars represent the percent of total cankers at each site that occurred in a given year.

Canker damage occurred throughout the bole length of sample trees (Figure 4A,B). The lowest confirmed canker occurred at $2.1 \mathrm{~m}$, and the highest confirmed canker occurred at $21.3 \mathrm{~m}$ (on a $27.9 \mathrm{~m}$ tall tree). The majority of cankers (601 of 770, or 78\%) occurred between 6-16 m on the tree (Figure $4 \mathrm{~A}$ ). 
The largest cankers ( $>15 \mathrm{~cm}$ wide) occurred in the middle of the bole, between 5-12 $\mathrm{m}$ (Figure 4B). The butt $\log (0-3.66 \mathrm{~m})$ is typically the most commercially valuable log. These results demonstrate that only $2.3 \%$ (18 of 770 ) of cankers occurred in this $\log$ (Figure $4 \mathrm{~A}$ ), and those that did were relatively small (mean width $=1.39 \mathrm{~cm}$; Figure $4 \mathrm{~B}$ ).

A

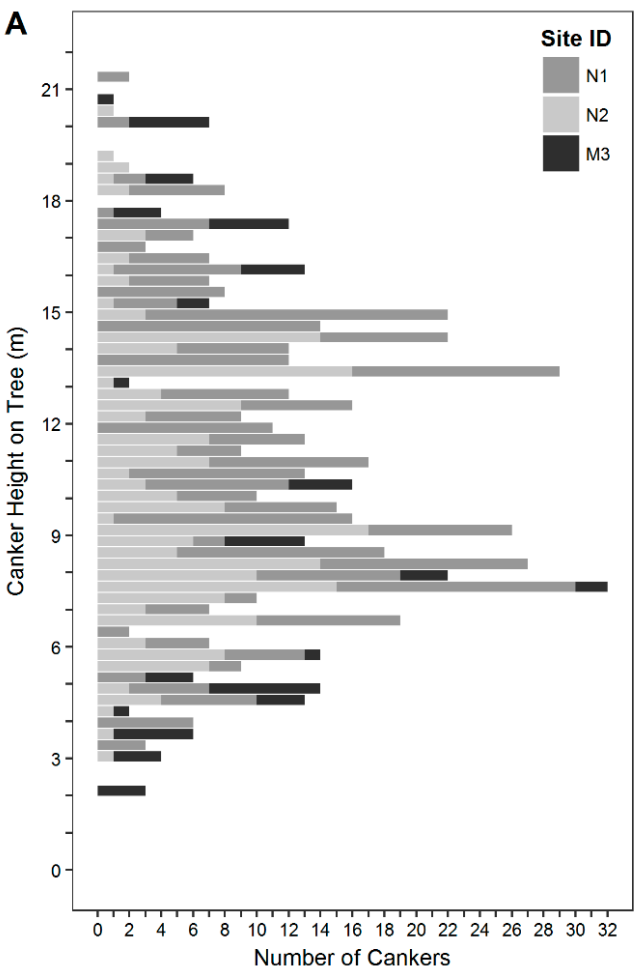

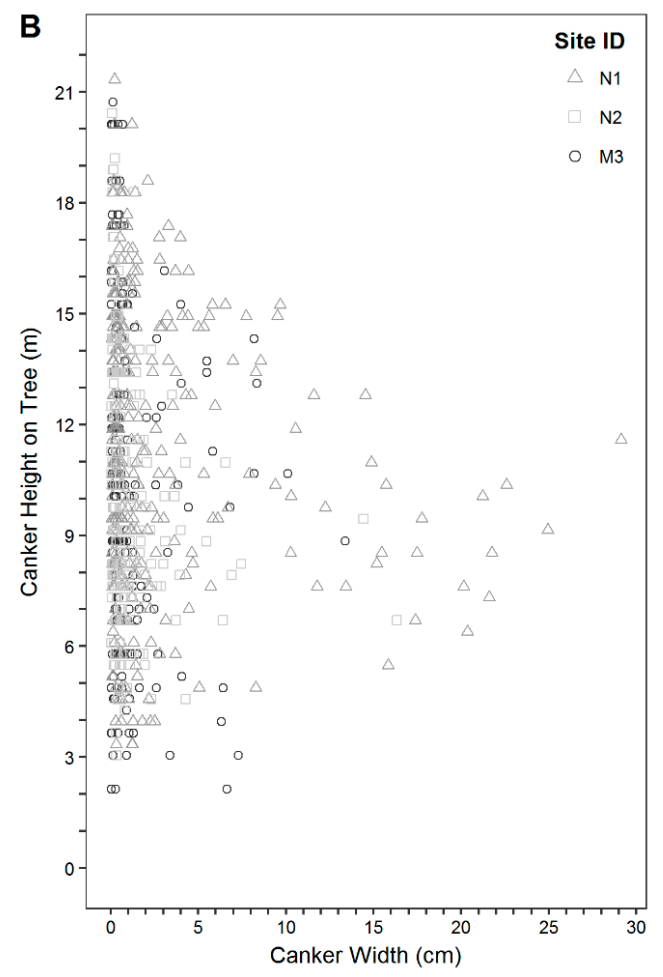

Figure 4. Tree height and Caliciopsis canker damage relationships conveyed via the (A) number of cankers and (B) the width of cankers at each $0.3 \mathrm{~m}$ height on the tree.

From the three sites, 36 white pine trees were sampled. At each site, mean dbh ranged from $24.4 \mathrm{~cm}$ to $30.2 \mathrm{~cm}$, while mean tree heights ranged from 22.1 to $23.7 \mathrm{~m}$. Mean tree volumes ranged from $0.51 \mathrm{~m}^{3}$ to $0.83 \mathrm{~m}^{3}$, while mean UNCR values ranged from $25.5 \%$ to $31.5 \%$ (data not shown). The ANOVA results indicate that the mean values were not significantly different across sites (all $p$-values $\geq 0.21$; Table A2). However, when thinning treatment was accounted for, trees from thinned stands were significantly larger with greater UNCR values than trees from unthinned stands (Table A2A). There were no consistent trends in tree measurements between trees with high and low Caliciopsis canker symptom severity (Table A2B). Furthermore, there were no significant interactions between thinning treatment and Caliciopsis symptom severity class for each tree metric (Table A2A,B).

The total number and summed width of cankers varied widely between sample trees, in part due to individual tree volumes ranging from 0.19 to $1.95 \mathrm{~m}^{3}$. On each tree, the canker incidence index ranged from 0 to 182.6 cankers (mean $=50.8$ cankers), while the canker severity index ranged from 0 to $357.8 \mathrm{~cm}$ (mean $=84.8 \mathrm{~cm}$ ). It should be noted that one outlier tree was removed from the dataset during analysis, as the tree was declining/dead at time of sampling and was identified as an outlier from the rest of the sample population. The outlier had a canker incidence index of 140.4 cankers and a canker severity index of $662.2 \mathrm{~cm}$.

Linear mixed effects models indicate that canker incidence and canker severity were significantly and negatively related to UNCR ( $p$-values were $<0.001$ and 0.002 , respectively). As UNCR increased, the incidence and severity of cankers decreased (Figure 5A,B). The median values were $27.7 \%$ for UNCR, 36.7 for canker incidence index, and $45.7 \mathrm{~cm}$ for canker severity index (data not shown). Of the 18 trees with UNCR values greater than 27.7\%, 14 had canker damage metrics (incidence and severity) 
below the median (Figure 5A,B), supporting the hypothesis that higher crown ratios are associated with reduced canker damage. No other fixed effects (thinning treatment, Caliciopsis symptom severity class, and all interactions) were statistically significant in the mixed effects models.
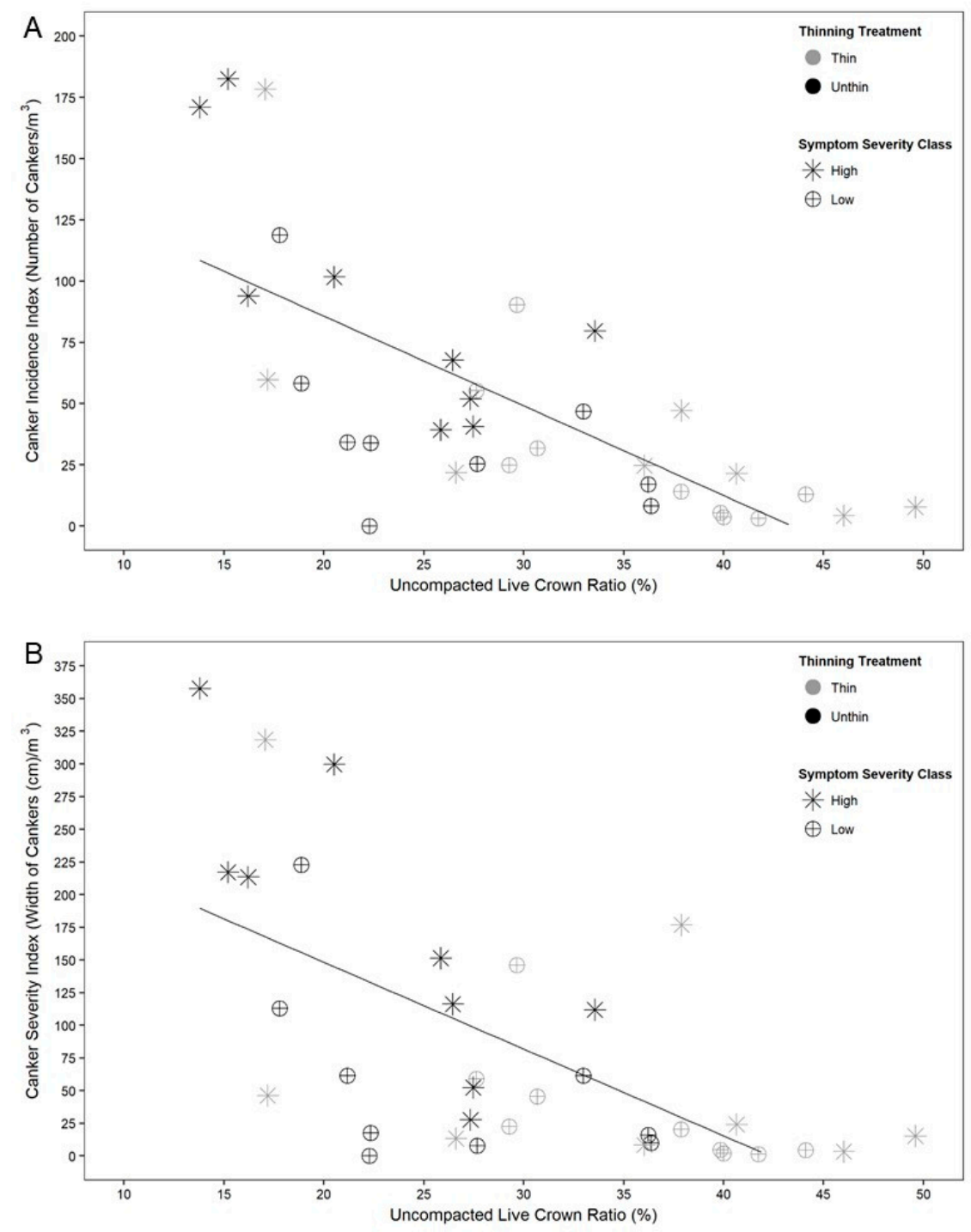

Figure 5. Canker incidence and severity measures associated with crown metrics. Linear mixed effects models were used to assess the relationship between uncompacted live crown ratio, (A) the canker incidence index (number of cankers $/ \mathrm{m}^{3}$ of tree; $p$-value $<0.001$ ), and (B) the canker severity index (width of cankers $/ \mathrm{m}^{3}$ of tree; $p$-value $=0.002$ ).

Tree growth declines $\left(D_{\text {scores }}<0\right)$ were frequently associated with increases in the number of cankers that year (Figure 6A,B), particularly since the mid-1970s. In general, the number of cankers increased when declines occurred, then decreased once the trees recovered (Figure 6A). At N1 and N2,

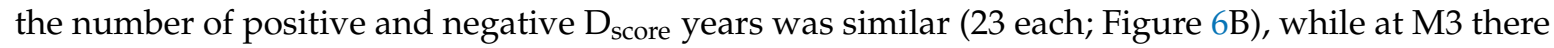

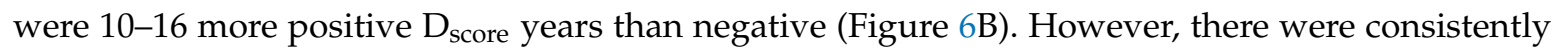

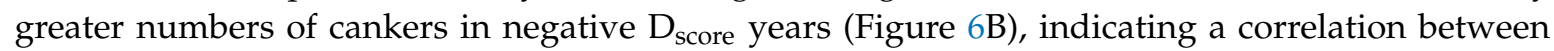
decline and canker occurrence. In all groups except low severity trees from M3, there were two to 21 times as many cankers in negative $\mathrm{D}_{\text {score }}$ years compared with positive $\mathrm{D}_{\text {score }}$ years (Figure 6B). Furthermore, high severity trees always produced greater numbers of cankers in decline years than did low severity trees (Figure 6A), supporting the hypothesis that external severity ratings can be used to assess which trees are experiencing greater damage. Additionally, these decline metrics were closely 
associated with trends in BAI values (Figure A1), which is expected as $\mathrm{D}_{\text {scores }}$ were calculated from BAI values.

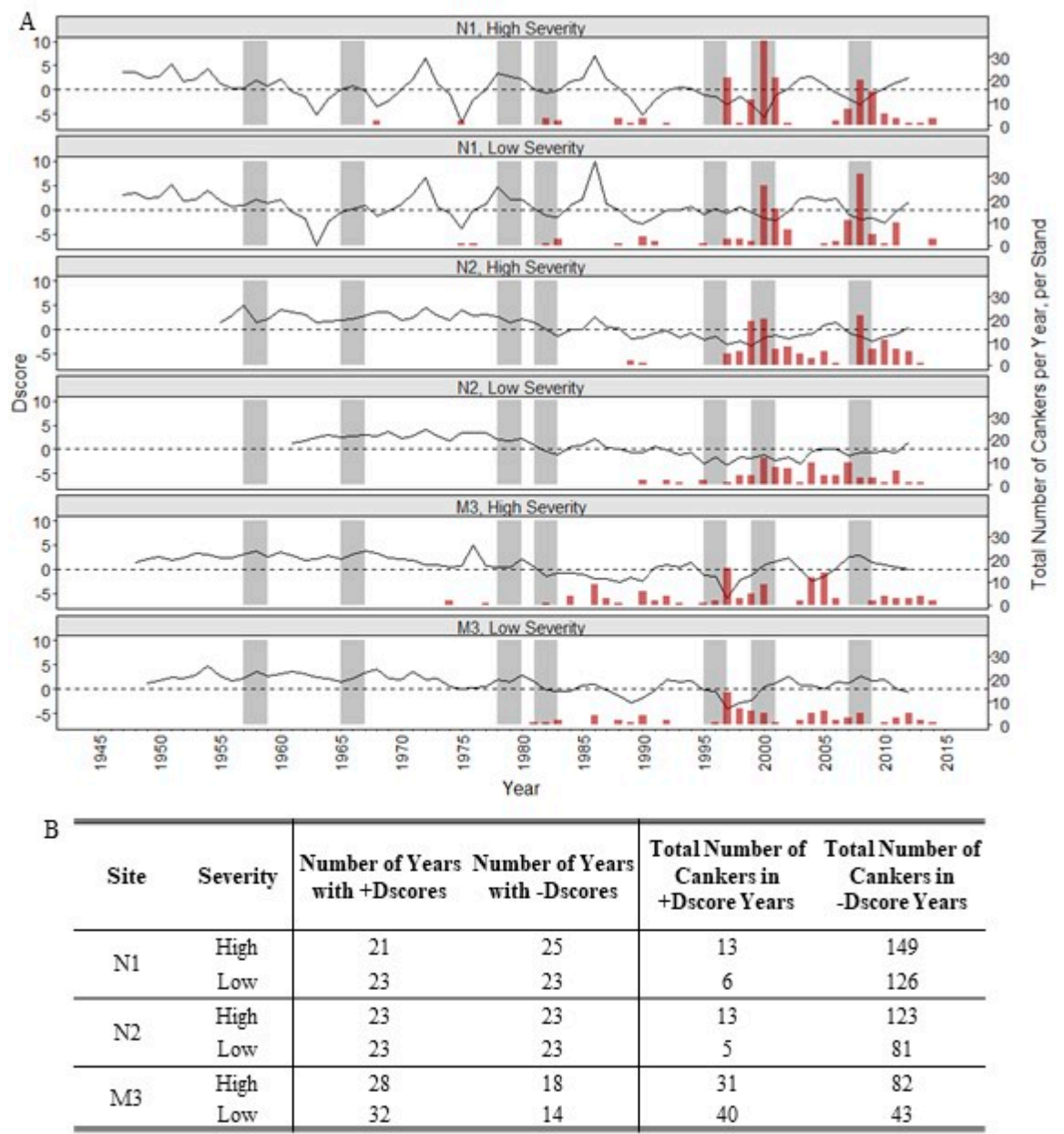

Figure 6. Decline scores ( $\mathrm{D}_{\text {scores }}$ ) associated with annual number of cankers, separated by site and Caliciopsis symptom severity class. (A) Black solid lines represent annual $\mathrm{D}_{\text {scores }}$ (averaged per severity class and site). Black horizontal dashed lines represent the decline cutoff; $\mathrm{D}_{\text {scores }}<0$ are declining stands. Gray vertical bars represent specific climatic events plus a 2-year post-event window (1957-1959, 1965-1967, 1978-1980, 1981-1983, 1995-1997, 1999-2001, 2007-2009). Red vertical bars represent the total number of cankers per severity class, per site, per year. (B) The sum of years and number of

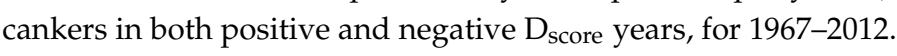

When evaluating $\mathrm{D}_{\text {scores }}$ and climatic events individually, there were no consistent trends: during each of the climatic events and the two-year response period, some stands experienced decline, some recovered, and others did not decline (Figure 6A). However, the years with the greatest number of cankers always occurred during a climatic stress period (Figure 6A), suggesting that climatic stress is associated with, or increases the likelihood of, canker occurrence.

Similar trends emerged when evaluating the size of cankers (canker width) and tree growth declines. In each group, the year with the highest total canker width occurred during a period of growth decline (Figure 7A). Across all sites, high severity trees experienced higher total canker widths, particularly high severity trees at N1 (Figure 7A). In negative $\mathrm{D}_{\text {score years, all sites experienced nearly }}$ twice as much canker damage in high severity trees compared to low severity trees (Figure 7B). In all groups, the year with the largest amount of canker damage occurred during a climatic disturbance period (Figure 7A). 


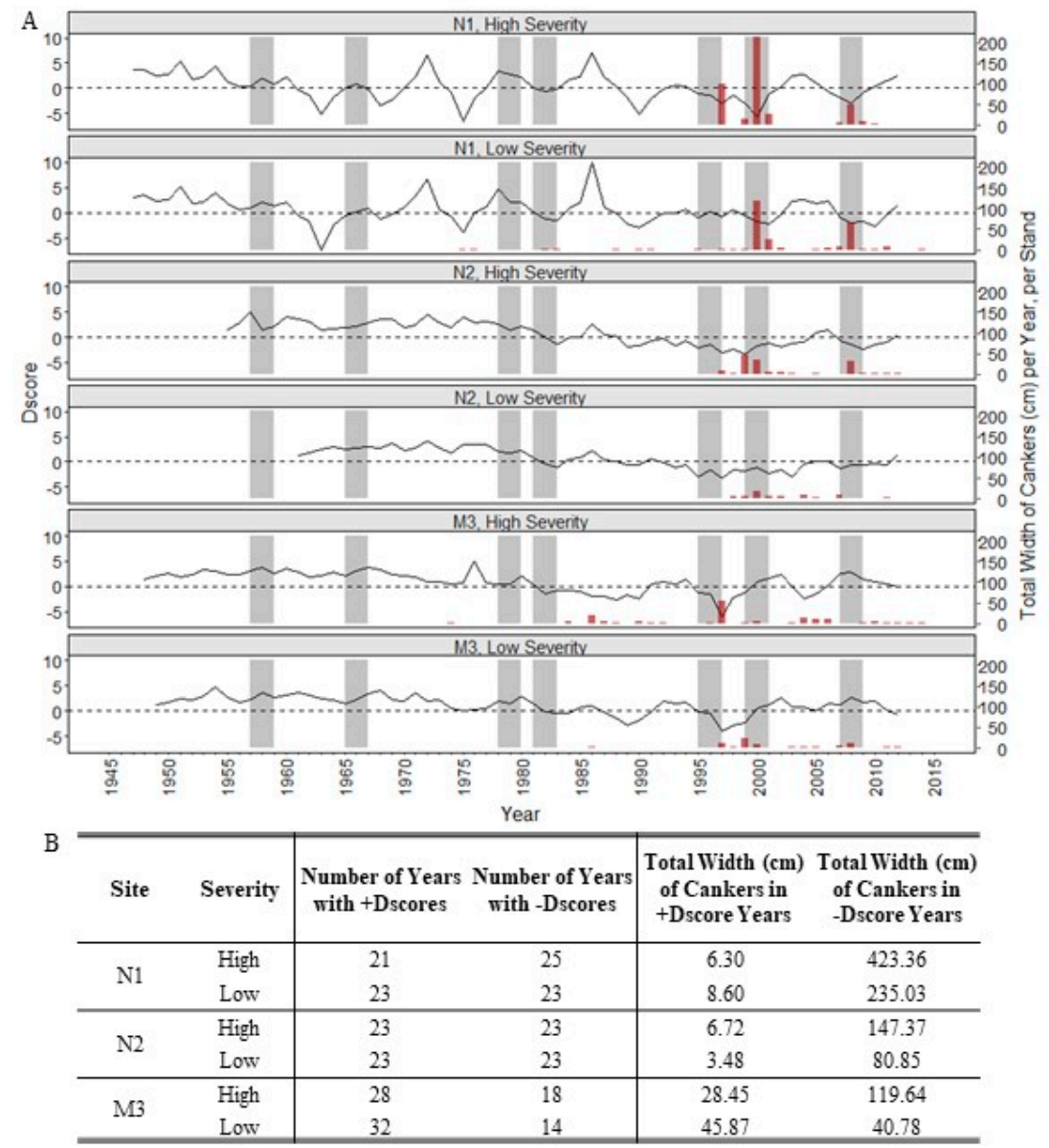

Figure 7. Decline scores ( $\left.\mathrm{D}_{\text {scores }}\right)$ associated with the annual summed width of canker damage, separated by site and Caliciopsis symptom severity class. (A) Black solid lines represent annual $D_{\text {scores }}$ (averaged per severity class and site). Black horizontal dashed lines represent the decline cutoff; $\mathrm{D}_{\text {scores }}$ $<0$ are declining stands. Gray vertical bars represent specific climatic events plus a 2-year post-event window (1957-1959, 1965-1967, 1978-1980, 1981-1983, 1995-1997, 1999-2001, 2007-2009). Red vertical bars represent the summed width $(\mathrm{cm})$ of cankers per severity class, per site, per year. $(\mathbf{B})$ The sum of

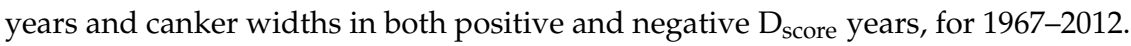

\section{Discussion}

The analyses presented above document a detailed investigation into the impacts of one specific tree disease, Caliciopsis canker. Trees often respond to stress agents relatively quickly, typically within three years. Annual growth rings, therefore, capture this response and provide a detailed record of tree- and stand-level disturbance history that can be used to document the impact of specific stressors and diseases. Our study reconstructed the history of one fungal pathogen, quantified its impact on tree crown and growth metrics, and applied whole-stem analysis to document tree-level infection incidence and severity. As a result, this study successfully used dendrochronological techniques for quantifying and assessing tree diseases.

The results from tree-level metrics (dbh, volume, crown metrics) showed that trees from thinned stands were larger (dbh, height, volume) with larger crowns (UNCR values; Table A2A), likely due to larger trees being retained at the time of thinning and improved growing conditions after thinning. Landowner records indicated that all thinned and unthinned stands at the three sites were similar and unmanaged until the most recent thinning. Our data shows that tree ages were similar between N1 and N2 stands, but M3 thinned trees were approximately 10 years younger than unthinned trees. Adjustments were made to account for tree size, however, there were still no significant differences in canker incidence or canker severity indices 
between thinned and unthinned stands ( $p>0.10$ for both indices). As the dendrochronology results show (Figures 6 and 7), much of the canker formation occurred prior to or just after thinning, indicating treatments likely had little long-term impact on a tree's response to $C$. pinea infections.

Based on the results from canker incidence (Figure 4A) and severity (Figure 4B) along the length of the tree bole, it is evident that most cankers occurred between 6-16 $\mathrm{m}$, and these also tended to be the largest cankers. These results indicate that stressed white pine at these shorter heights are more likely to suffer canker damage, which supports the recommendation to reduce white pine stand density when trees are taller than $6 \mathrm{~m}$ [62].

When comparing canker incidence and severity to crown metrics, both the number of cankers and the width of cankers reported similar negative relationships with UNCR values, indicating that external visual assessments of crown health can be indicative of internal canker damage. Trees with an UNCR value of $30 \%$ or greater had reduced canker damage (Figure $5 \mathrm{~A}, \mathrm{~B}$ ). When managing for reduced risk of Caliciopsis canker, we therefore recommend selecting residual trees with a 30\% UNCR or greater, and a low canker severity rating, which will likely result in a productive, healthy stand that experiences less damage from Caliciopsis canker. Similarly, D'Amato et al. [63] analyzed white spruce (Picea glauca [Moench] Voss) live crown ratios in relation to eastern spruce budworm (Choristoneura fumiferana Clemens) attack. They found that a crown ratio of $40 \%$ or greater was optimal for maintaining tree vigor and growth and increasing stand resistance to budworm attack [63], which lends support to our suggestion of maintaining at least $30 \%$ UNCR in white pine stands.

Based on reconstructions of canker history, sites often experienced elevated canker incidence in the same years (Figure 3), indicating regional synchrony in canker occurrence. This suggests that, in addition to site factors, an external force is likely influencing canker incidence and severity. Recent studies on other fungal pathogens have shown a marked increase in infection occurrence associated with changes in climate [64], which could also be driving the increase in Caliciopsis canker damage on white pine. In the present study, the year with the greatest number and width of cankers at each site was associated with a drought period (Figure 6A, Figure 7A). Further research on the direct impact of climate change on both the pathogen and the host are needed, however, to fully test these relationships.

While these results are significant, these data do not indicate cause and effect. To address whether canker damage results in tree decline or if decline predisposes trees to Caliciopsis canker, we evaluated the relationship between $D_{\text {scores }}$ and canker damage metrics. Increases in both canker number and canker width typically occur one to three years after growth decline has already begun, frequently initiated by a climatic event (Figure 6A, Figure 7A). This finding suggests that canker damage occurs at the time of, or just after, another stress is already acting on the tree. This can further be seen in the overlap between increased canker years and climatic stress events (Figure 6A, Figure 7A). When stressors occur, increases in canker damage occur one to two years later, suggesting that $C$. pinea causes increased infection and damage in predisposed, stressed trees.

Collectively, these results illustrate distinct associations between tree growth declines and Caliciopsis canker damage, providing evidence that supports recent observations of declining white pine stands in eastern North America [28,33,36]. In turn, this demonstrates a strong negative relationship between tree health and Caliciopsis canker occurrence, particularly as damage increased. The data suggest that when trees are healthy and maintaining consistent growth, Caliciopsis canker is not a significant problem. This relationship between declining trees and disease has been well studied, and it is commonly accepted that stressed trees are more susceptible to disease agents [14,65]. In Maine and New Hampshire, one of the most common climate stressors is drought [15], which reduces tree resources and potentially increases white pine susceptibility to Caliciopsis canker. Furthermore, when drought stress is combined with other stressors (e.g., harvesting, windstorms, flooding), susceptibility may continue to increase. One option is to thin stands to reduce density, increase resource availability, increase tree vigor, and reduce susceptibility [15]. D'Amato et al. [66] found that thinning red pine stands resulted in increased drought resistance, particularly in younger stands. These results underscore the need to minimize stress in white pine stands in order to reduce the susceptibility to Caliciopsis canker. 


\section{Conclusions}

Native pests and pathogens can cause significant changes in New England's white pine forests, particularly when they act in ways not previously documented. While C. pinea was first documented in New England in 1880, reports of Caliciopsis canker damage began increasing in the early 1990s. This study confirms Caliciopsis canker damage, and further supports previous reports that Caliciopsis cankers have been present and increasing in incidence and severity since the mid-1970s in Maine and New Hampshire. The number and size of cankers are also closely linked to decreasing tree vigor. Climatic events that stress white pine (e.g., droughts, flooding) appear to be associated with increases in canker damage. These stress events typically occur 1-3 years before increases in canker damage, supporting the hypothesis that $C$. pinea is frequently associated with already stressed trees.

To reduce Caliciopsis canker damage, our findings suggest that proactive silviculture practices can be effective, particularly when retaining trees with live crown ratios greater than $30 \%$, a low canker severity rating, and reducing stand densities when trees exceed $6 \mathrm{~m}$ in height. Selecting such trees as crop trees will likely result in increased tree vigor and growth, decreased susceptibility to Caliciopsis canker, and in turn a decreased number and size of cankers. These actions can maintain the value of standing white pine [32], and in some instances can even increase the value by allowing currently infected trees to recover. One important consideration, however, is the timing and intensity of thinning. Care should be taken to minimize stress to the stand; harvesting should not be conducted if other stress events are co-occurring or have occurred recently. In sum, Caliciopsis canker is a potentially detrimental fungal disease both ecologically and economically; however, with monitoring and proactive management, damage can potentially be reduced and white pine can continue its role as a signature species in New England.

Author Contributions: Development of field sampling protocols and collection of field data, K.K.L.C., W.H.L., and I.A.M; processing samples, K.K.L.C.; entering data conducting preliminary analysis, K.K.L.C.; writing-original draft preparation, K.K.L.C.; data analysis—review and editing, W.H.L., S.F., and I.A.M., writing-review and editing, W.H.L., S.F., and I.A.M. All authors have read and agreed to the published version of the manuscript.

Funding: This work was supported by the USDA Agricultural Research Cooperative Agreement 58-0202-4-003; USDA Forest Service, Forest Health Protection grants 16-DG-11420004-197 and 16-DG-11920004-218; USDA Forest Service, Northeastern Area State and Private Forestry; and USDA National Institute of Food and Agriculture, Hatch Project \#ME0-31708 through the Maine Agricultural and Forest Experiment Station. Additionally, Hancock Lumber graciously donated the use of their land, trees, and foresters' time and effort. Maine Agricultural and Forest Experiment Station Publication Number 3720.

Acknowledgments: We graciously thank the individuals who helped fell trees, collect field data, and process samples: Bruce Allen and Kyle Lombard with New Hampshire Division of Forests and Lands; William Ostrofsky and Wayne Searles with Maine Forest Service; Colin Bridge-Koenigsberg, Garth Dixon, Jereme Frank, Savannah Haines, Joshua Savoy, and Matthew Todd with the University of Maine; and Olivia Box with Hamilton College. We also appreciate the guidance and statistical expertise of Bill Halteman, who assisted with data analysis and interpretation.

Conflicts of Interest: The authors declare no conflict of interest.

\section{Appendix A}

Table A1. Average climate conditions by site, measured on an annual basis from 1944-2014.

\begin{tabular}{cccc}
\hline Climate Measure & N1 & N2 & M3 \\
\hline Mean annual temperature $\left({ }^{\circ} \mathrm{C}\right)$ & $7.10^{\mathrm{a}}$ & $7.56^{\mathrm{b}}$ & $6.91^{\mathrm{a}}$ \\
Minimum annual temperature $\left({ }^{\circ} \mathrm{C}\right)$ & $0.79^{\mathrm{a}}$ & $1.22^{\mathrm{b}}$ & $0.80^{\mathrm{a}}$ \\
Maximum annual temperature $\left({ }^{\circ} \mathrm{C}\right)$ & $13.40^{\mathrm{a}}$ & $13.90^{\mathrm{b}}$ & $13.03^{\mathrm{c}}$ \\
Total annual precipitation $(\mathrm{cm})$ & $114.22^{\mathrm{a}}$ & $111.20^{\mathrm{a}}$ & $117.88^{\mathrm{a}}$ \\
\hline
\end{tabular}

* Temperature and precipitation values were averaged for all years, 1944-2014; $n=71$ observations per site. Data was obtained from the PRISM (Parameter-elevation Regressions on Independent Slopes Model) Climate Group (2017). ${ }^{a-c}$ Means in a row without a common superscript letter differ $(p<0.01)$, as analyzed by one-way ANOVA and Tukey Post Hoc Tests. 
Table A2. Summary statistics for 36 sampled eastern white pine (Pinus strobus L.) trees. In each site, 12 trees were felled and destructively sampled, 6 each per thinning treatment ("Treat;" Thin, Unthin), and within each treatment 3 per symptom severity class (High, Low). The p-values and degrees of freedom are reported; $p$-values in italics are significant at the $p \leq 0.10$ level. The means are reported for both (A) thinning treatment and (B) Caliciopsis symptom severity class.

\begin{tabular}{|c|c|c|c|c|c|c|c|}
\hline \multirow{2}{*}{$\begin{array}{c}\text { Site } \\
\text { Thinning Treatment }\end{array}$} & \multicolumn{2}{|c|}{ N1 } & \multicolumn{2}{|c|}{ N2 } & \multicolumn{2}{|c|}{ M3 } & \multirow{2}{*}{$\begin{array}{c}\text { Two-Way ANOVA (Model: Metric } \sim \text { Treat } \times \\
\text { Severity + Error(Site/(Treat } \times \text { Severity)) }\end{array}$} \\
\hline & Thin & Unthin & Thin & Unthin & Thin & Unthin & \\
\hline $\begin{array}{c}\text { Diameter at breast } \\
\text { height }(\mathrm{cm})\end{array}$ & 25.7 & 23.1 & 31.0 & 23.6 & 37.0 & 23.5 & $\begin{array}{c}p<0.01, d f=1 \text { (treat) } \\
p=0.09, d f=1 \text { (severity) } \\
p=0.21, d f=1 \text { (site) } \\
p=0.75, d f=1 \text { (treat } \times \text { severity) }\end{array}$ \\
\hline Tree height (m) & 23.1 & 21.6 & 23.7 & 20.6 & 25.1 & 22.3 & $\begin{array}{c}p<0.01, d f=1 \text { (treat) } \\
p=0.05, d f=1 \text { (severity) } \\
p=0.57, d f=1 \text { (site) } \\
p=0.91, d f=1 \text { (treat } \times \text { severity) }\end{array}$ \\
\hline Tree volume $\left(\mathrm{m}^{3}\right)$ & 0.59 & 0.43 & 0.80 & 0.44 & 1.23 & 0.44 & $\begin{array}{c}p<0.01, d f=1 \text { (treat) } \\
p=0.16, d f=1 \text { (severity) } \\
p=0.23, d f=1 \text { (site) } \\
p=1.00, d f=1 \text { (treat } \times \text { severity) }\end{array}$ \\
\hline $\begin{array}{l}\text { Uncompacted live } \\
\text { crown ratio }(\%)\end{array}$ & 29.9 & 21.1 & 37.6 & 24.9 & 35.4 & 27.7 & $\begin{array}{c}p<0.01, d f=1 \text { (treat) } \\
p=0.28, d f=1 \text { (severity) } \\
p=0.43, d f=1 \text { (site) } \\
p=0.92, d f=1 \text { (treat } \times \text { severity) }\end{array}$ \\
\hline & & & & & 3 & & \\
\hline Site & \multicolumn{2}{|c|}{ N1 } & \multicolumn{2}{|c|}{ N2 } & \multicolumn{2}{|c|}{ M3 } & Two-Way ANOVA (Model: Metric $\sim$ Treat $\times$ \\
\hline Symptom Severity & High & Low & High & Low & High & Low & \\
\hline $\begin{array}{l}\text { Diameter at breast } \\
\text { height }(\mathrm{cm})\end{array}$ & 20.8 & 28.1 & 27.5 & 27 & 31.2 & 32.7 & $\begin{array}{c}p<0.01, d f=1 \text { (treat) } \\
p=0.09, d f=1(\text { severity }) \\
p=0.21, d f=1 \text { (site) } \\
p=0.75, d f=1 \text { (treat } \times \text { severity) }\end{array}$ \\
\hline Tree height (m) & 20.9 & 23.9 & 22.4 & 21.8 & 23.1 & 24.7 & $\begin{array}{c}p<0.01, d f=1 \text { (treat) } \\
p=0.05, d f=1 \text { (severity) } \\
p=0.57, d f=1(\text { site }) \\
p=0.91, d f=1 \text { (treat } \times \text { severity) }\end{array}$ \\
\hline Tree volume $\left(\mathrm{m}^{3}\right)$ & 0.34 & 0.68 & 0.65 & 0.59 & 0.91 & 0.97 & $\begin{array}{c}p<0.01, d f=1 \text { (treat) } \\
p=0.16, d f=1 \text { (severity) } \\
p=0.23, d f=1 \text { (site) } \\
p=1.00, d f=1 \text { (treat } \times \text { severity) }\end{array}$ \\
\hline $\begin{array}{l}\text { Uncompacted live } \\
\text { crown ratio }(\%)\end{array}$ & 21.8 & 29.2 & 31.4 & 31.0 & 31.9 & 33.7 & $\begin{array}{c}p<0.01, d f=1 \text { (treat) } \\
p=0.28, d f=1 \text { (severity) } \\
p=0.43, d f=1 \text { (site) } \\
p=0.92, d f=1 \text { (treat } \times \text { severity) }\end{array}$ \\
\hline
\end{tabular}




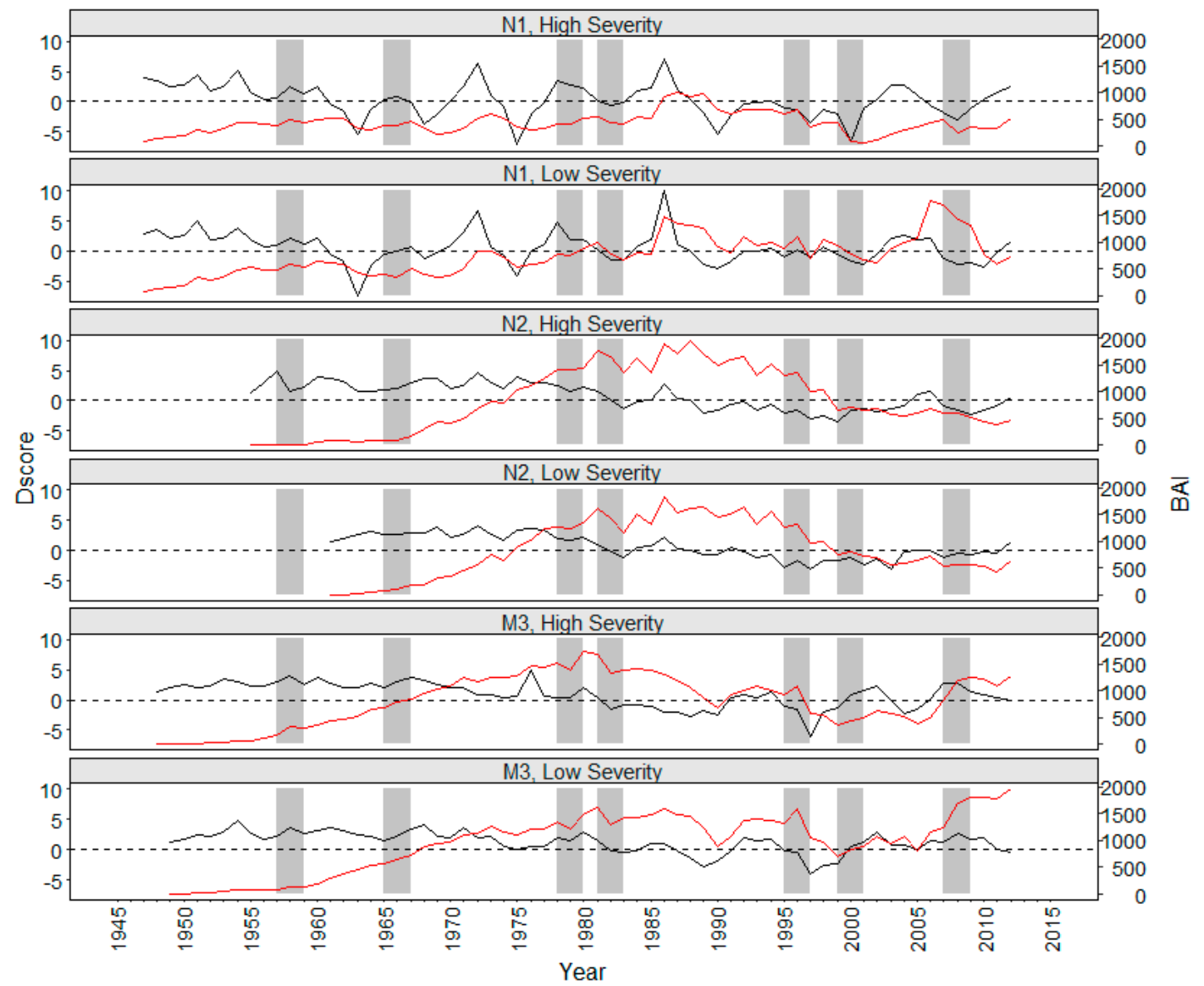

Figure A1. Decline scores ( $\mathrm{D}_{\text {scores }}$ ) associated with Basal Area Increment (BAI) values, separated by site and Caliciopsis symptom severity class. Black solid lines represent annual $\mathrm{D}_{\text {scores }}$ (averaged per severity class and site). Black horizontal dashed lines represent the decline cutoff; $\mathrm{D}_{\text {scores }}<0$ are declining stands. Red solid lines represent BAI values (averaged per severity class and site). Gray vertical bars represent specific climatic events plus a 2-year post-event window (1957-1959, 1965-1967, 1978-1980, 1981-1983, 1995-1997, 1999-2001, 2007-2009).

\section{References}

1. Weed, A.S.; Ayres, M.P.; Hicke, J.A. Consequences of climate change for biotic disturbances in North American forests. Ecol. Monogr. 2013, 83, 441-470. [CrossRef]

2. Boyd, I.L.; Freer-Smith, P.H.; Gilligan, C.A.; Godfray, H.C.J. The consequence of tree pests and diseases for ecosystem services. Science 2013, 342, 1235773. [CrossRef] [PubMed]

3. Ramsfield, T.D.; Bentz, B.J.; Faccoli, M.; Jactel, H.; Brockerhoff, E.G. Forest health in a changing world: Effects of globalization and climate change on forest insect and pathogen impacts. For. Int. J. For. Res. 2016, 89, 245-252. [CrossRef]

4. Ayres, M.P.; Lombardero, M.J. Assessing the consequences of global change for forest disturbance from herbivores and pathogens. Sci. Total Environ. 2000, 262, 263-286. [CrossRef]

5. Logan, J.A.; Régnière, J.; Powell, J.A. Assessing the impacts of global warming on forest pest dynamics. Front. Ecol. Environ. 2003, 1, 130-137. [CrossRef]

6. Dukes, J.S.; Pontius, J.; Orwig, D.; Garnas, J.R.; Rodgers, V.L.; Brazee, N.; Cooke, B.; Theoharides, K.A.; Stange, E.E.; Harrington, R.; et al. Responses of insect pests, pathogens, and invasive plant species to climate change in the forests of northeastern North America: What can we predict? Can. J. For. Res. 2009, 39, 231-248. [CrossRef] 
7. Seidl, R.; Thom, D.; Kautz, M.; Martin-Benito, D.; Peltoniemi, M.; Vacchiano, G.; Wild, J.; Ascoli, D.; Petr, M.; Honkaniemi, J.; et al. Forest disturbances under climate change. Nat. Clim. Chang. 2017, 7, 395-402. [CrossRef]

8. Wyka, S.A.; Munck, I.A.; Brazee, N.J.; Broders, K.D. Response of eastern white pine and associated foliar, blister rust, canker, and root rot pathogens to climate change. For. Ecol. Manag. 2018, 423, 18-26. [CrossRef]

9. Costanza, K.K.L.; Whitney, T.D.; McIntire, C.D.; Livingston, W.H.; Gandhi, K.J.K. A synthesis of emerging health issues of eastern white pine (Pinus strobus) in eastern North America. For. Ecol. Manag. 2018, 423, 3-17. [CrossRef]

10. Linder, S.; Benson, M.L.; Myers, B.J.; Raison, R.J. Canopy dynamics and growth of Pinus radiata: I. Effects of irrigation and fertilization during a drought. Can. J. For. Res. 1987, 17, 1157-1165. [CrossRef]

11. Maier, C.A.; Teskey, R.O. Internal and external control of net photosynthesis and stomatal conductance of mature eastern white pine (Pinus strobus). Can. J. For. Res. 1992, 22, 1387-1394. [CrossRef]

12. Vose, J.M.; Swank, W.T. Effects of long-term drought on the hydrology and growth of a white pine plantation in the southern Appalachians. For. Ecol. Manag. 1994, 64, 25-39. [CrossRef]

13. Boyer, J.S. Biochemical and biophysical aspects of water deficits and the predisposition to disease. Annu. Rev. Phytopathol. 1995, 33, 251-274. [CrossRef] [PubMed]

14. Desprez-Loustau, M.-L.; Marçais, B.; Nageleisen, L.-M.; Piou, D.; Vannini, A. Interactive effects of drought and pathogens in forest trees. Ann. For. Sci. 2006, 63, 597-612. [CrossRef]

15. Livingston, W.H.; Kenefic, L.S. Low densities in white pine stands reduce risk of drought-incited decline. For. Ecol. Manag. 2018, 423, 84-93. [CrossRef]

16. Hepting, G.H. Climate and forest diseases. Annu. Rev. Phytopathol. 1963, 1, 31-50. [CrossRef]

17. Schoeneweiss, D.F. Predisposition, stress, and plant disease. Annu. Rev. Phytopathol. 1975, 13, $193-211$. [CrossRef]

18. Schoeneweiss, D.F. The role of environmental stress in diseases of woody plants. Plant. Dis. 1981, 65, 308-314. [CrossRef]

19. Ayres, P.G. Growth responses induced by pathogens and other stresses. In Response of Plants to Multiple Stresses; Mooney, H.A., Winner, W.E., Pell, E.J., Chu, E., Eds.; Academic Press: Cambridge, MA, USA, 1991; pp. 227-248.

20. Van Arsdel, E.P. Environment in relation to white pine blister rust infection. In Biology of Rust Resistance in Forest Trees: Proceedings of a NATO-IUFRO Advanced Study Institute; USDA Forest Service Miscellaneous Publication No. 1221; University of Idaho: Moscow, ID, USA, 1972.

21. Peck, C.H. Report of the Botanist. Annu. Rep. N. Y. State Mus. Nat. Hist. 1880, 33, 32.

22. Fitzpatrick, H.M. Revisionary studies in the Coryneliaceae. II. The genus Caliciopsis. Mycologia 1942, 34, 489-514. [CrossRef]

23. Funk, A. Studies in the genus Caliciopsis. Can. J. Bot. 1963, 41, 503-543. [CrossRef]

24. Munck, I.A.; Livingston, W.H.; Lombard, K.; Luther, T.; Ostrofsky, W.D.; Weimer, J.; Wyka, S.; Broders, K. Extent and severity of Caliciopsis canker in New England, USA: An emerging disease of eastern white pine (Pinus strobus L.). Forests 2015, 6, 4360-4373. [CrossRef]

25. Ray, W.W. Pathogenicity and cultural experiments with Caliciopsis pinea. Mycologia 1936, 28, $201-208$. [CrossRef]

26. Delatour, C. Contribution à l'étude du Caliciopsis pinea Peck: Résultats complémentaires d'inoculations artificielles. Ann. Sci. For. 1969, 26, 285-295. [CrossRef]

27. Capretti, P. Caliciopsis pinea Peck parassita di Pinus pinaster e Pinus insignis. Phytopathol. Mediterr. 1978, 17, 101-104.

28. Lombard, K. Caliciopsis Canker (Pine Canker): Caliciopsis Pinea; UNH Cooperative Extension Publication: Durham, NH, USA, 2003; p. 1.

29. Lanier, L.; Delatour, C. Étude du pouvoir pathogène du Caliciopsis pinea Peck sur le Pin maritime des Landes. Rev. For. Fr. 1967, 5, 332-337.

30. Mech, A.M.; Asaro, C.; Cram, M.M.; Coyle, D.R.; Gullan, P.J.; Cook, L.G.; Gandhi, K.J.K. Matsucoccus macrocicatrices (Hemiptera: Matsucoccidae): First report, distribution, and association with symptomatic eastern white pine in the southeastern United States. For. Entomol. 2013, 106, 2391-2398. [CrossRef]

31. Fitzpatrick, H.M. Monograph of the Coryneliaceae. Mycologia 1920, 12, 206-237. [CrossRef] 
32. Costanza, K.K.L.; Crandall, M.S.; Rice, R.W.; Livingston, W.H.; Munck, I.A. Economic implications of a native tree disease, Caliciopsis canker, on the white pine (Pinus strobus) lumber industry in the northeastern United States. Can. J. For. Res. 2019, 49, 521-530. [CrossRef]

33. Asaro, C. What's killing white pine in the highlands of western Virginia? In Forest Health Review; Virginia Department of Forestry: Charlottesville, VA, USA, 2011; p. 12.

34. USDA Forest Service. 2000 Forest Health Highlights: New Hampshire; USDA Forest Service, Northeastern Area State and Private Forestry: Durham, NH, USA, 2000; p. 2.

35. O'Brien, J. White pine branch mortality. In 2007 Michigan Forest Health Highlights; Michigan Department of Natural Resources, Forest, Mineral, and Fire Management Division: Lansing, MI, USA, 2007; pp. $19-20$.

36. Rose, J.A. Caliciopsis canker of white pine (Caliciopsis pinea). Market. Bull. 2011, 2.

37. Bordeleau, C.; Gagnon, G.; Innes, L.; Lachance, C.; Marchand, L.; Morneau, L.; Paré, D.; Prémont, M.; Simard, S. Insectes, Maladies, et Feux Dans les Forêts Québécoises en 2003; Gouvernement du Québec, Ministère des Ressources Naturelles, de la Faune et des Parcs: Québec, QC, Canada, 2004; p. 60.

38. Swetnam, T.W.; Thompson, M.A.; Sutherland, E.K. Spruce Budworms Handbook: Using Dendrochronology to Measure Radial Growth of Defoliated Trees; Agricultural Handbook No. 639; USDA Forest Service: Washington, DC, USA, 1985; p. 38.

39. Boulanger, Y.; Arsenault, D. Spruce budworm outbreaks in eastern Quebec over the last 450 years. Can. J. For. Res. 2004, 34, 1035-1043. [CrossRef]

40. Speer, J.H.; Holmes, R.L. Effects of Pandora moth outbreaks on ponderosa pine wood volume. Tree-Ring Res. 2004, 60, 69-76. [CrossRef]

41. Siegert, N.W.; McCullough, D.G.; Liebhold, A.M.; Telewski, F.W. Dendrochronological reconstruction of the epicentre and early spread of emerald ash borer in North America. Divers. Distrib. 2014, 20, 847-858. [CrossRef]

42. Welsh, C.; Lewis, K.; Woods, A. The outbreak history of Dothiostroma needle blight: An emerging forest disease in northwestern British Columbia, Canada. Can. J. For. Res. 2009, 39, 2505-2519. [CrossRef]

43. Griffith, G.E.; Omernik, J.M.; Bryce, S.A.; Royte, J.; Hoar, W.D.; Homer, J.W.; Keirstead, D.; Metzler, K.J.; Hellyer, G. Ecoregions of New England (Color Poster with Map, Descriptive Text, Summary Tables, and Photographs): Reston, VA, U.S. Geological Survey (Map Scale 1:1,325,000). 2009. Available online: https://www.epa.gov/eco-research/ecoregions-publications (accessed on 3 March 2020).

44. PRISM Climate Group, Oregon State University. PRISM Climate Data. 2017. Available online: http: //prism.oregonstate.edu (accessed on 9 July 2017).

45. Fraver, S.; Bradford, J.B.; Palik, B.J. Improving tree age estimates derived from increment cores: A case study of red pine. For. Sci. 2011, 57, 164-170.

46. Costanza, K.K.L. Fungal DNA Used to Assess Communities Associated with Caliciopsis Canker Damage in New England's Pinus Strobus Forests. Ph.D. Thesis, University of Maine, Orono, ME, USA, 2017.

47. USDA Forest Service. Forest Inventory and Analysis National Core Field Guide. Volume 1: Field Data Collection Procedures for Phase 2 Plots. Version 6.1; USDA Forest Service: Washington, DC, USA, 2014; p. 433.

48. Rasband, W.S. 1997-2016. ImageJ. US National Institutes of Health: Bethesda, MD, USA. Available online: https://imagej.nih.gov/ij/ (accessed on 21 February 2017).

49. Regent Instruments Canada Inc. WinDENDRO for Tree-Ring Analysis, Version 2012b; Regent Instruments: Québec, QC, Canada, 2012.

50. Grissino-Mayer, H.D. Evaluating crossdating accuracy: A manual and tutorial for the computer program COFECHA. Tree-Ring Res. 2001, 57, 205-221.

51. Schulz, A.N.; Mech, A.M.; Asaro, C.; Coyle, D.R.; Cram, M.M.; Lucardi, R.D.; Gandhi, K.J.K. Assessment of abiotic and biotic factors associated with eastern white pine (Pinus strobus L.) dieback in the Southern Appalachian Mountains. For. Ecol. Manag. 2018, 423, 59-69. [CrossRef]

52. Honer, T.G. Standard Volume Tables and Merchantable Conversion Factors for the Commercial Tree Species of Central and Eastern Canada; Information Report FMR-X-5; Canadian Department of Forestry and Rural Development, Forest Management Research and Services Institute: Ottawa, ON, Canada, 1967; p. 21.

53. R Core Team. R: A Language and Environment for Statistical Computing; R Foundation for Statistical Computing: Vienna, Austria, 2018; Available online: https://www.R-project.org/ (accessed on 3 March 2020).

54. Bates, D.; Maechler, M.; Bolker, B.; Walker, S. Fitting linear mixed-effects models using lme4. J. Stat. Softw. 2015, 67, 1-48. [CrossRef] 
55. Bunn, A.G. Statistical and visual crossdating in R using the dplR library. Dendrochronologia 2010, 28, 251-258. [CrossRef]

56. Livingston, W.H.; Pontius, J.; Costanza, K.K.L.; Trosper, S. Using changes in basal area increments to map relative risk of HWA impacts on hemlock growth across the Northeastern U.S.A. Biol. Invasions 2017, 19, 1577-1595. [CrossRef]

57. New Hampshire Department of Environmental Services (NHDES). New Hampshire Drought Management Plan. NHDES-WRB-90-1; 1990; p. 48. Available online: https://drought.unl.edu/archive/plans/drought/state/ NH_1990.pdf (accessed on 16 September 2015).

58. Lombard, P.J. Drought Conditions in Maine, 1999-2002: A Historical Perspective. Water-Resources Investigations Report 03-4310; U.S. Geological Survey: Augusta, ME, USA, 2004; p. 47.

59. National Oceanic and Atmospheric Administration (NOAA). Climatological Rankings. 2017. Available online: https://www.ncdc.noaa.gov/temp-and-precip/climatological-rankings (accessed on 25 October 2017).

60. Munck, I.A.; Luther, T.; Wyka, S.; Keirstead, D.; McCracken, K.; Ostrofsky, W.; Searles, W.; Lombard, K.; Weimer, J.; Allen, B. Soil and stocking effects on Caliciopsis canker of Pinus strobus L. Forests 2016, 7, 269. [CrossRef]

61. Johnson, A.H.; McLaughlin, S.B.; Adams, M.B.; Cook, E.R.; DeHayes, D.H.; Eagar, C.; Fernandez, I.J.; Johnson, D.W.; Kohut, R.J.; Mohnen, V.A.; et al. Synthesis and conclusions from epidemiological and mechanistic studies of red spruce decline. In Ecology and Decline of Red Spruce in the Eastern United States; Eager, C., Adams, M.B., Eds.; Springer: New York, NY, USA, 1992; pp. 385-412.

62. Livingston, W.H.; Munck, I.A.; Lombard, K.; Weimer, J.; Bergdahl, A.; Kenefic, L.S.; Schultz, B.; Seymour, R.S. Field manual for managing eastern white pine health in New England. Maine Forest and Agricultural Experiment Station. Misc. Publ. 2019, 764, 20.

63. D'Amato, A.W.; Troumbly, S.J.; Saunders, M.R.; Puettmann, K.J.; Albers, M.A. Growth and survival of Picea glauca following thinning of plantations affected by eastern spruce budworm. North. J. Appl. For. 2011, 28, 72-78. [CrossRef]

64. Wyka, S.A.; Smith, C.; Munck, I.A.; Rock, B.N.; Ziniti, B.L.; Broders, K. Emergence of white pine needle damage in the northeastern United States is associated with changes in pathogen pressure in response to climate change. Glob. Chang. Biol. 2017, 23, 394-405. [CrossRef] [PubMed]

65. Manion, P.D. Tree Disease Concepts; Prentice Hall: Englewood Cliffs, NJ, USA, 1991; p. 402.

66. D'Amato, A.W.; Bradford, J.B.; Fraver, S.; Palik, B.J. Effects of thinning on drought vulnerability and climate response in north temperate forest ecosystems. Ecol. Appl. 2013, 23, 1735-1742. [CrossRef] 